\title{
COVID-19 in Romania-the militarization of social life and the banality of death
}

\author{
Florin Poenaru ${ }^{1}$
}

Published online: 27 September 2021

(c) The Author(s), under exclusive licence to Springer Nature B.V. 2021

On March 11, 2020, Romanian President Klaus Iohannis addressed the media about the pandemic after meeting with the inter-institutional working group tasked to tackle its effects and he explained the problem to the public. At the time there were only 30 confirmed cases and no deaths in the country, which led Iohannis to declare that reports about an apocalyptic killing virus are a myth and exaggerate the danger of the virus, which he dismissed as being comparable to the ordinary flu. He even mocked some news reports that highlighted the urgency of the situation. In a mere two weeks, his story had changed. Now, the President acknowledged that the pandemic created a threat humanity had not experienced in recent history and only the toughest measures would help overcome it. He signed an emergency decree that suspended the normal functioning of state institutions and introduced one of the strongest lockdowns in Europe for two months.

This abrupt reversal in attitude exemplifies the response of the Romanian state to the ongoing pandemic. It was not rooted in objective ignorance. Nor was it based in weighing and considering the inevitable unknowns of the pandemic that leave even the best scientists guessing. Instead, these responses express the fundamental weakness of the Romanian state. After 30 years of neoliberal ideology that mandated a retreat of the state from society and the celebration of "markets" as the most efficient mechanism to organize all spheres of life, the feebleness of state action was inevitable. The pandemic highlighted tragically, what everyone already knew: most of Romania's state institutions are dysfunctional and crumbling. From this perspective, the institutional disarray has been much more dangerous than the virus itself.

Emergencies and contingent events like the pandemic stretch the limits of states and raise extraordinary challenges to their normal functioning. Shortcomings and failures are inevitable in the USA and Western Europe, but the consequences in relatively poor countries like Romania are catastrophic. In this article, I present four examples of Romanian state failure during the pandemic. Certainly, there are more,

Florin Poenaru

poenaru.florin@gmail.com

1 Faculty of Sociology and Social Work, University of Bucharest, Schitu Măgureanu, No 9, Sector 1, Bucharest, Romania 
but I want to highlight those I think that underscore particular weaknesses in the political organization of capitalism in Eastern Europe, but, first, I would like to define "failure" of state power. It is not the outcome of some malfunctioning mechanism as it is the case, say, when an engine fails. Nor is it akin to a botched operation, the situation in which one tries to do something (like saving people from a sinking ship), but for various reasons (bad preparation, ill judgment, incompetence, bad luck, etc.) it fails to accomplish the task. The type of failure I am interested in is structural. It is the failure of the state to be the guardian of the public interest. Moreover, this failure is part of the normal functioning of the Romanian state in the past three decades, if not more. Failures amid the pandemic are not an exception, not an accident and not related to the extraordinary events that followed the global spread of COVID. Rather, it bespeaks entrenched patterns of state action that were only magnified and brought to the fore during the medical crisis.

In Romania, the state has lacked the authority and capacity to know and to act properly regarding the general needs of ordinary citizens. ${ }^{1}$ State agencies carry on in a manner that is clueless, tentative, and meandering. To compensate, officials, in the name of the pandemic, have introduced harsh forms of militarism and authoritarianism. They tried to hide, rather than to explain, their actions and their outcomes. This fundamental weakness of the state is undoubtedly an outcome of neoliberal ideology and policies that have left the state largely a shell, but class and relations of accumulations are essential. Important segments of the Romanian bourgeoisie, especially owners of medium and large businesses, prefer a weak state that is lethargic and does not interfere. Such a state is a perfect companion for public-private partnerships that drain the state budget into private pockets, the main source of profit for the local capital. Similarly, global firms stand to benefit from an anemic and badly run state that is unable to collect tax, let alone control complex forms of fiscal optimization. Large white-collar segments have come to prefer a feeble state. They thrive precisely where the state is absent by offering their "expertize" against hefty fees and honorariums, mostly in EU projects, while aiming for an "optimization" of the state-that is, a further retreat of the state and more leeway for experts and private firms.

These weaknesses and contradictions in the Romanian state have resulted in outcomes that significantly diverge from the way other states have managed the pandemic, which highlights the uneven ways in which states are slotted into the global capitalist hierarchies, which have been made explicit during the pandemic. For example, George Baca (2020) insightfully wrote about the manner in which state authorities in South Korea used the COVID-19 pandemic to enhance previous forms of surveillance and extraction of minute data about citizens in favor of the technocorporate governing elite bent on shielding its economic interests and social status. Early successes in halting the spread of the virus mystified the way corporate leaders

\footnotetext{
${ }_{1}$ I single out Romania here because it is the main focus of this commentary, but it was not an exceptional case. Countries in post-communist Central and Eastern Europe, as well as former Yugoslavia, shared similar patterns. Failures of the state were also endemic in advanced capitalist economies like the UK and the USA, albeit for different reasons.
} 
used the pandemic to expand their power. Long (2020) vividly described the dystopian surveillance mechanisms the Chinese authorities put in place, allegedly to keep trace of the virus, in practice to monitor people to frightening details. Davies (2021) wryly noted the transformation of hotels in Australia and New Zeeland into detention centers and testing facilities, in a fundamental reversal of what hospitality means. The scale of surveillance in these, and other similar cases, makes Foucault's Panopoticon look like a pleasant place.

By focusing on the vicissitudes of state power during the pandemic, I want to highlight how the pandemic became the cause of great state mobilization. Everywhere in the world, politicians, state managers, and administrators stepped up and made public efforts to stop the menace, if not for the sake of humanity as such, at least for their own citizens. The pandemic ushered in several rounds of state action while projecting fantastic images of fear and impending crisis. For example, at the beginning of the pandemic, Giorgio Agamben controversially warned that the medical crisis provided states the opportunity to impose a "state of exception" in order to limit individual freedoms and to impose undemocratic forms of biopolitics (Agamben 2020). Leaving aside the various details of the polemics that Agamben ignited, this fear of an all powerful state should be tempered-at least for now-by the example of the ineffectual one in Romania and in other similar neoliberal paradises like Brazil (Ortega and Orsini 2020), Peru Mitrovic (2020), and India (Roy 2021). Many of these state leaders exhibited an inability to act meaningfully to stop the transmission and instead led to the exercise of bare force in relation to citizens. Rather than constructing a biopolitics, the state could only administer, through authoritarian measures, a cynical necropolitics. With the specter of the pandemic in mind but also with that of the climate catastrophe in the horizon, state necropolitics might be the norm rather than a failure.

Below I trace the unfolding of this necropolitics in four major areas. The first topic I discuss is the fate of Romanian migrant seasonal workers during the pandemic and how their precarious condition expresses the hierarchically structured and uneven nature of the EU economy and also the inability of the Romanian state to implement a biopolitical program for its citizens. Then, in the second section, I discuss how the (mis-)functioning of the medical sector during the pandemic was construed as a further argument for its privatization, a process already underway. Thirdly, I examine how the contradictory and ill thought response the Romanian state gave to the economic fallout of the pandemic led to the political mobilization of the petite bourgeoisie which materialized in the ascension to power of a postfascist party. Finally, I show how the violence and militarization of everyday life the state engendered during the pandemic was the ultimate symptom of its failure. Rather than elicit the trust of the citizens, it contributed to the delegitimation of any response to the perils of the virus, thus leading to an exponential growth of deniers. 


\section{A brief timeline}

When the first corona-patient was hospitalized in Romania on February 26, 2020, an interim government was leading the country. The Social Democrats had lost their majority in 2019 and the right-wing National Liberal Party and their allies USRPLUS were unable to form a government. Amid this stalemate, President Klaus Iohannis discovered that the pandemic could be of political use to his fledgling plans to form a government. He used the crisis as a catalyst for a compromise and the leader of the National Liberals, Ludovic Orban, becomes the Prime Minister shortly before the lockdown.

Behind assurances that the situation is under control, the authorities' response was erratic. They delayed the closing of schools and universities and failed to develop guidelines for online teaching. The beginning of the 2020 spring semester was chaotic. Unclear protocols coupled with poor coordination between central government and local institutions led to the explosion of COVID-19 infections in hospitals across the country. Some were placed under strict quarantine, enforced by the military, after infections that started there got out of control. Much like in the USA and Western Europe, many Romanians came to see hospitals as danger zones: the most likely sources of infection. These problems cascaded as people suffering from other illnesses had to find alternatives to hospitals or postpone their doctor visits. These malfunctions led to higher excess death rates, a problem exacerbated because Romanian authorities erroneously hospitalized all COVID-19 patients, even those asymptomatic or with mild symptoms. This led to overcrowding in hospitals and to an unnecessary stretch of resources in an already highly underfunded and understaffed system. As a result, many people protested and some even escaped the hospitals, only to be dragged back by the police.

During the summer of 2020, these problems worsened. Lacking sufficient funds and infrastructure, the state was unable to systematically test and trace. Public health offices at the county level were overwhelmed and unable to properly register and monitor reported cases, let alone find new ones. These administrative failures provided an opening for the virus to spread at new levels. While on paper physical distancing measures and the wearing of masks were still mandatory, they were not enforced. Under pressure from the hospitality industry, the government caved in and most of the restrictions were lifted, except for a late night curfew, which was not respected by and large. Hence, by autumn cases soared to new heights. With local and parliamentary elections looming, politicians and administrators came to understand the pandemic as a catch-22 and they approached it by thinking of the political costs at the expense of human life.

Such was the case of the President Iohannis. He was unwilling to deal with the consequences of postponed elections and chose to keep the economy going instead of bringing the pandemic under control. Such inaction led to COVID-19 patients filling hospitals and dead patents piled up by the hundreds each day. The authorities deflected attention from governmental failures to the victims of the disease for their lack of individual responsibility, which contributed to the normalization of pandemic related deaths. The old, weak, and sick die anyway, so there is no need to 
make everyone suffer by imposing stricter regulations. This was the rationalization the authorities offered. COVID-19 deniers and critics of the restrictions suddenly flooded mainstream TV channels and other media.

The elections were held in early December as the pandemic raged. Unsurprisingly, the turnout was one of the lowest in history. Gnarled by the pandemic, the National Liberals came in second. However, they remained in power by virtue of a coalition with center-right USRPLUS and the party representing the Hungarian minority, UDMR, under the leadership of Florin Cîțu, the new Prime Minister. Cîțu, a self-proclaimed libertarian in the past, vowed to fully open the economy and lift all restrictions - a promise he deliverd at the beginning of the summer of 2021 . He also promised to implement a vaccination campaign that will immunize half of the Romanian population by August 1, 2021. This was and continues to be a failure. As I write this (mid September 2021), Romania has the worst vaccination rate in the EU bar Bulgaria, with only $32 \%$ of the population fully vaccinated. The vaccination nonethelees brought the number of infections down to almost zero at the beginning of the summer of 2021, but its slowdown ever since led to an explosion of cases which announce the beginning of the 4 th wave and a new period of unpredictability.

Let me zoom in now closer to aformentioned key themes.

\section{Corona-workers: the disposable essentials}

When Italy, France, Germany, and the UK introduced lockdowns in the spring of 2020 more than 250.000 Romanians, $20 \%$ of them from Italy, had little choice but to return home. As economic activities shut down, firms disposed of migrant workers in an instant with little compensation and no health insurance. Such numbers stem from the way Eastern European workers have become the backbone of Western European economies. The European Union's (EU) strategies for "global competiveness" have rested on low salaries and the exploitation of migrant labor forces. Within these nested hierarchies, Romanian laborers are important resources-always ready to perform backbreaking jobs for low wages, while also being able to move legally across the EU as citizens of a member country. Non-EU migrants, refugees and sans-papiers do not enjoy this status. By virtue of having a EU passport, Romanians decrease the costs of their relocation for casual labor and thus contribute to lowering the expenses of hiring them-not to mention downward pressure on wages throughout the Euro-zone. It is a structural element of the manner in which EU capitalism functions and reproduces itself.

Romanian officials, and even workers, have transformed this exploitative structure as a symbol of privilege. Western and local journalists, aligned with the interests of transnational capital, typically praise the mobility of the laborers from Eastern part of the EU and celebrate the accession of these subordinate members as a success story of the post-socialist transition and of the EU extension to the East (see for a typical example Dunlop 2020). In a cynical way, they are right: for about four million Romanians labor migrants not being exploited at home would have been an even worse fate. Nevertheless, this is so until the crisis hits. In 2020, as in 2008, casual migrant laborers were the first to pay the price and pack their bags. 
Returning Romanian workers faced a horrible situation. They were forced to wait at borders in long, humiliating lines. Then, they were doubly stigmatized once they arrived home. First, news reports depicted returning workers as carriers of the disease, infecting the nation. Second, right wing politicians chastised them for being unemployed and likely to be living off state allowance. Suddenly, the public image of the Romanian labor migrants dramatically shifted. They went from being national heroes who bravely, but tragically, left their home country in search of a better future, to pariahs and parasites, bringing back the virus and the perils of disease and poverty. This rapid change was visible also in the language used to describe them: from "diaspora," the positive term employed to designate the social vectors that propelled Klaus Iohannis to presidency in 2014, to "migrants," a derogatory appellation that marked their foreignness, their externality to the social body.

While lockdowns in Western Europe created surplus labor in the East, they also led to a shortage of workforce for the spring harvest of 2020. The same Western European countries faced the prospect of agricultural production rotting in the fields and the severe disruption of the food chains. García-Colón (2020) documented this situation through an apt comparison between the fate of the agricultural workers in Western Europe and those in the USA during the pandemic. In this way, he analyzed the broader processes through which states and corporations alternately mobilize and demobilize precarious and casual labor to keep the price of labor as low as possible, while extracting the maximum value from this labor. As Costi Rogozanu and I argue, the urgent demand for Romanian laborers during the lockdown embodies the hierarchical and uneven political economy of the EU (Poenaru and Rogozanu 2020). In this way, multinational corporations bring Romanian workers as casual working bodies to richer countries, in complete disregard for their safety and with the acquiescence of the state. This treatment dovetailed their second-hand nature as EU citizens and their disposability. Unable to protect and incorporate them in meaningful social security programs, the Romanian state introduced an exception to the state of exception in order to allow as many workers to go abroad for work in an extremely perilous situation.

Guarantees and reassurances from western governments and private companies proved to be in vain. Working and living conditions were inappropriate even for "normal" times, let alone during the pandemic. Payment was not so handsome as initially touted and employers seriously violated the rights of the workers by confiscating their passports and by using quarantine as an opportunity to discipline labor. The revolt of the disgruntled Romanian workers on social media was immediately crushed. Employers confiscated their phones or restricted the access to internet. Faced with mounting evidence of abuses, the Romanian Labor Minster vacillated. Predictably, a large number of workers contracted the virus. Slaughterhouses in Germany, where many Romanians worked, became extraordinary hubs of virus transmission. Some workers died because of the virus; others went down with it while lacking access to basic care.

The disposable essential workers became the focal point during the pandemic. They kept the economy going and also the social edifice in place at the expense of their health and their lives. By virtue of their position, they also revealed the fundamentally unjust, unequal, gendered, and racialized hierarchies that characterize the 
global division of labor, and the one in the EU in particular. The Romanian example shows how the state itself is complicit in the active creation of precarious, casual and disposable working bodies. The frontline laborers were also the ones who could articulate political demands during the pandemic: from Amazon workers in the USA, to nurses in Brazil and Spain, to agricultural workers in Romania. The pandemic crisis showed not only their precarious situation and highly disposable nature, but it also revealed their immense (potential) power. Without the work of these essentials, economies and societies would collapse. This was extremely close to happening in spring 2020 (and thereafter), but it was ultimately prevented by entranced patterns of labor control, both local and global.

\section{How to privatize hospitals while they are on fire}

The Romanian health system is one of the worst in the EU. A 2019 EU report made this crystal clear, detailing the feeble nature of the health system (State of health of the EU 2019). To begin with, the Romanian healthcare system is the most underfunded in the EU, both as percentage of GDP (under 5\% in Romania, compared to close to $10 \%$ the EU average) and per capita. Unsurprisingly, Romania is one of the countries with the lowest life expectancy in the EU (75,3 years). Over $10 \%$ of the population is uninsured and around 6\% of the population does not have access to medical treatment when they need it. Also, based on data from 2016, Romania had the highest rate of preventable deaths in the EU. A dearth of doctors and medical staff stems from the excessive rates of emigration.

Romania's moribund public health system came under new attacks a few weeks before the pandemic. The Ministry of Health introduced the idea for a new law that will allow private healthcare agents greater access to state funding. The practice had already been in place, as the public health system depended on private companies for blood testing as it lacked these basic facilities. The new provisions aimed not only to generalize these predatory practices but also to extend them to emergency services. As a result of this bill, the Romanian government's trifling healthcare budget will be divided among state and more private actors. The corporate giveaway to private health care firms will further starve state hospitals and hasten their collapse by exacerbating the overcrowding and the lack of necessary equipment. In turn, it will ensure a continuous stream of "patient-clients" to the private sector.

The opening up of state budget to private agents will also entail the development of a different market that of private health insurance. It also exists today, but the size is modest. This will change. State officials used an apt description of what is going to happen. They compared health insurance with the insurance of cars. If people want better coverage and extras, they should pay for a more expensive package, if they can afford it. If not, they will just get the basic one provided by the state, which will be able to cover fewer treatments in increasingly collapsing hospitals. To round up the picture, the Health Minister who initially drafted this bill was previously employed as a surgeon by one of the largest private networks of hospitals in Romania. Because prices are higher in the private sector, the state subsidy for each patient will not be enough, so people who will be treated in the private sector will have to 
co-pay. This will create a clear distinction between those who will be able to afford care in the private system and those who will have to rely solely on an increasingly depleted public sector.

The pandemic put the implementation of the bill on the backburner. The daily management of the health care system was entrusted to the Secretary of State in charge of Emergency Situations. One of his first decisions was to repurpose major public hospitals for COVID-19 patients only, at the expense of other illnesses. Private hospitals and clinics shut down and applied for government support schemes. The situation seemed under control during the lockdown despite the fact that many hospitals become sources of COVID-19 infections rather than cure. The situation degenerated once the rate of infections and hospitalization went through the roof. Note these dates: November 4, 2020, December 25, 2020, January 2, 2021, January 5, 2021, and January 29, 2021. They represent days in which a hospital treating COVID-19 patients caught fire. Twenty people died and many more were injured. Dilapidated infrastructure, poor equipment, and overcrowding were the main causes of the incidents. Inexplicably, the government reduced the funds allocated to the health care system in the 2021 budget.

The problems of the Romanian health care system were magnified by the pandemic. Certainly, it was miraculous that doctors and nurses, amid acute conditions of scarcity and understaffing, kept the system from disintegrating. However, death rates bring into dramatic relief the failing health care system. The Romanian Minister of Health admitted in a press conference on May 13, 2021, that state authorities failed to report between 5.000 and 10.000 COVID19 deaths since the beginning of the pandemic. At the moment of writing, the official death toll is close to 35,600 so that is quite a high proportion of the total. These are deaths caused by the virus that are known and have been registered as such, but not added to the total. Certainly, more remain unknown and they constitute part of the excessive death rate that the National Institute of Statistics reports every month. This "avalanche of numbers," as Marco D'Eramo aptly called it-mis- and underreported as they are-conceal in fact wider socio-economic and political forces that led to the transformation of death into a banality during the pandemic (D'Eramo 2020). The defunding of the health care system is such a force. Previous pressures for the privatization of health care, which dramatically hampered the general functioning of the system and especially its response to the pandemic, resurfaced in the face of its near collapse.

What has been surprising though was the lack of public pressure for a complete overhaul of the public health care system and its proper funding. The importance to do so should have been made clear by the pandemic, especially since private hospitals and clinics walked away from their duties and refused to deal with COVID-19 cases (except for highly expensive PCR testing). Complicated and serious cases are usually treated in public hospitals, even though they are not always up to standard and already compete for funding with the private ones. Instead, the pandemic functioned as an opposite vector: it led to renewed calls for the privatization of hospitals, and generally for more freedom to private interests in the health care system. The inability of the state to act and inspire confidence in general solutions contributed to this contradictory outcome 
during the pandemic. If anything, the pandemic fomented even more individualism, private solutions and a staunch defense of particular, factional interests. The emergence of the petite bourgeoisie as significant actor during the pandemic is indicative of this aspect.

\section{The insurgence of petite bourgeoisie}

Contradictory and clearly biased decisions of the authorities sparked the political mobilization of the local petite bourgeoisie. ${ }^{2}$ Governmental directives mandated that shopping malls remain open, while small markets closed or moved in open air. Large retail supermarkets closed later than mom-and-pop stores. Gas stations, predominantly owned by large western firms, functioned 24/7 and boosted their profits by expanding their services and becoming de facto supermarkets with higher prices. Public schools remained closed, while private ones functioned unhindered. Regulations heavily restricted the activity of small shops, restaurants, cafes, and hairdressers, while workers on construction sites, usually organized by international developers, continued their activity unimpeded. As usual, government institutions were predisposed to serve the interests of the big capital to the detriment of the small entrepreneurs and, especially, the workers.

Amid these conflicts of power, the local hospitality industry flew the flag of resistance by highlighting the loss of jobs because of restrictions. Business leaders in this sector pressured the government to lift pandemic related regulations. Other petite bourgeois segments such as independent artists, shopkeepers, small agricultural farmers, and transporters joined the opposition. Ironically, they enlisted the help of their employees, which in general are highly exploited and poorly paid, but faced with unemployment, they protested together with their bosses to keep businesses open. During the lockdown, the government offered assistance to petite bourgeois enterprises by postponing rent and covering furloughs, but once the lockdown ended they had to rely on revenues from customers and any restrictions would limit them. Ultimately, the lobby was successful and led to more confusing governmental decisions. By late 2020 and early 2021, for example, bars and restaurants remained open until $11 \mathrm{pm}$, while many other economic activities mandatorily shut down at $9 \mathrm{pm}$.

In Romania, amid the stress and anxiety that resulted from the pandemic, the political insurgency of the petite bourgeoisie was evident in the ascension of a new party. AUR, which in Romanian means gold, stands for the Alliance for the Unification of Romanians. Initially it started as a coalition of forces keen to promote the unification of Romania and the Republic of Moldova. In the 2020 parliamentary

\footnotetext{
2 Arno Mayer (1975) defined petite bourgeoisie as being comprised of individuals who do not predominantly do manual labor, have certain skills, are self-conscious about being neither lower nor upper class, but aspire upward and do so individualistically, consider private property sacrosanct, are susceptible to co-optation and patronage, are fearful of sinking down to manual occupation and mobilize politically only in times of severe stress.
} 
elections, it managed to gain $9 \%$ of the vote and thus spectacularly entered the parliament. Skillfully using the social media, the party leaders managed to capture the dissatisfaction of the petite bourgeoisie caused by the inconsistent and jaundiced measures of the government. Leaders also lured businesses by promising policies of economic protectionism. In addition, the party thrived on class struggle. It addressed the genuine fears of people in small and medium cities in Romania facing ominous economic and social perspectives. Couched in the language of Nation and Church, the party presented itself as giving voice and political hope to segments of the population that were severely impoverished long before the pandemic. Moreover, the lockdown and the resulting economic downturn deepened these dynamics. The conspiracy theories that the party peddled were both structurally ingrained in its ideology, but also ready-made and combustible devices for mobilization in uncertain times. The white collar and bourgeois segments in big cities, which enjoyed a steady job and could work from the comfort of their homes, were vilified for mindlessly and selfishly supporting restrictions. The outreach of the party among petite bourgeois strata, especially in small and mid-sized cities, became even more evident in March 2021 when tens of thousands of people joined the party's marches across Romania to end restrictions. Most remarkably, AUR also tapped into the anger of Romanian migrants who were either forced to stay abroad in dire circumstances or had to return to Romania and face an ignoble status. Bartenders, truck drivers, asparagus pickers, care and construction workers, but also low level white collars, adhered to the movement. They not only voted for the party, but also were actively involved in political agitation. If the pandemic continues, and all indications are that it will, the expectation is that this "post-fascist party" (Tamas 2001) will consolidate and grow, especially since leftist and social-democratic options are historically foreclosed in Romania (Poenaru 2019).

However, what AUR did in fact was to politically weaponize a different type of necropolitics, succinctly expressed by one of their supporters during a rally I observed. Leaders provocatively asked its supporters "what is the difference between being killed by the virus or being killed by hunger and poverty"? The risk of catching the virus and even being killed by it was deemed preferable to a state of economic destitution. This reflected at once two overlapping strands: an ingrained individualism and a complete disbelief in state solutions. Both strands reflect the ethos of this class forged in the transition period that was characterized by the retreat of the state and the myth of self-made agents. Nevertheless, rather than constituting a proper form of opposition to the state, the political insurrection of the petite bourgeoisie actually helped the state. By highlighting individual solutions and extolling a narrow concern with private property and private interests, there was no real pressure on the state to function for the public good. Instead, the state was happy to place the responsibility on the citizens and thereafter police their actions. 


\section{The militarization of social life}

In an excellent unpublished thesis, Cristina Cristea documented how the Ministry of Interior, Marcel Vela, assumed public communications related to the pandemic. In his daily briefings, dressed in a military jacket, he highlighted the number of fines issued by the police and the number of people reprimanded or arrested for breaking the law. Only then he would turn his attention to the activity of doctors and the state of the COVID-19 patients. In this way, the media and government officials constructed the virus as if it were an external enemy against the nation. The nonchalance of government officials during the first days of the pandemic gave way to clarion calls to defend the nation with military force. This militarization of the state response became literal. When the lockdown was announced, fully armed military vehicles occupied the streets of most cities around the country. The military spending of $2 \%$ of GDP for NATO-member countries that former president Donald Trump demanded and the Romanian President Iohannis dully accepted was not in vain, apparently. At least the military was ready to fight the virus, if not the health care system.

Militarization, repression, and a blunt display of authoritarianism became the distinctive modus operandi of the state. During the lockdown, Romanians could leave their houses only for work, to buy food, and for medical emergencies. In all cases, the government forced citizens to write a legally biding declaration that could send one to jail if the information was proven inaccurate. Some people were fined simply for wrongly filling in this declaration. Sport activities and walking were restricted only to one's neighborhood and a lot of people were fined for ignoring this provision and venturing a bit further. The number of fines administered during the lockdown attracted the attention of international media. The emergency legislation increased the level of fines from approximately 400 euros to a maximum of 40.000 euros. Such levels were unprecedented and unquestionably absurd.

In addition, the police acted with brutality against people allegedly violating the lockdown. Roma population in rural areas and small cities was predominantly targeted, but instances of excessive force were also reported in big cities. The mandatory wearing of masks constituted the perfect pretext for the exercise of state's forms of (micro) violence: police, sometimes in plain clothes, patrolled public spaces, from agricultural markets to busy streets, in order to reprimand or fine those not wearing a mask properly. In many cases, people were beaten up for refusing to comply and at least one person was killed. State violence, in various guises, exacerbated during the pandemic, and instead of showing state's determination and power, it showcased its weakness and inability to act beyond repression.

\section{Conclusion}

Pandemic in Romania crystalized and magnified previously existing social circumstances, which also delineated the possibilities and limits of state intervention. The cheap and disposable work of the Romanian migrants proved essential to save the food chains of Western Europe from collapsing, but it exacted the painful price upon workers, making them vulnerable to the rapidly spread virus. After years of neoliberal 
divestment, the local healthcare system barely survived, and the mounting death toll illustrates that the Romanian public health system merely manages death rather than safeguard health. Class privileges prove to be crucial if one is to navigate this system as well as all other social institutions. The petite bourgeoisie was the most vocal against restrictions, sensing correctly that the corporate middle class is better shielded against the worst effects of the pandemic. Unsurprisingly, their agitation did not seek improvements in public institutions. Instead, they used the sense of crisis to mobilize support that contributed to the success of a post-fascist party enter Parliament, in keeping with a similar resurgence of such forces elsewhere. Faced with deep levels of societal distrust and lacking the proper means to act, the state resorted to militarism and authoritarianism to fight the virus, which, as expected, only increased public resistance to state measures. Coordinated by the military, the local vaccination campaign stagnates as the country heads towards wave four. The failure of the state to act decisively, and productively mobilize citizens, provided the conditions for conspiracy theories about the vaccine to flourish. More a symptom of distrust rather than stupidity, conspiracy theories reflect the citizens' low level of confidence in public authorities. There is no vaccine for this malaise.

Acknowledgements The author thanks George Baca for his tremendous help with writing and revising this piece.

\section{References}

Agamben, Giorgio. 2020. The state of exception provoked by an unmotivated emergency. Position Politics. Available here: https://positionspolitics.org/giorgio-agamben-the-state-of-exception-provoked-by-anunmotivated-emergency/. Accessed July 14.

Baca, G. 2020. Eastern surveillance, Western malaise, and South Korea's COVID-19 response: Oligarchic power in Hell Joseon. Dialectical Anthropology 44: 301-307. https://doi.org/10.1007/ s10624-020-09609-y.

D'Eramo, Marco. 2020. The avalance of numbers. Sidecar. Available here: https://newleftreview.org/sidecar/ posts/avalanche-of-numbers. Accesed July 12.

Davies, W. 2021. Friend or threat. London Review of Books. Vol. 43 No. 12 - 17 June 2021.

Dunlop, T. 2020. Căpsuni și COVID. De ce trebuie lăsați sezonierii români să muncească în alte țări (Strawberries and COVID. Why Romanian seasonal workers must be allowed to work in other countries). Libertatea. Available here: https://www.libertatea.ro/opinii/coronavirus-marea-britanie-muncitori-romani2959647. Accesed July 12.

European Commission. 2019. State of health of the EU: Romanian (https://ec.europa.eu/health/sites/default/ files/state/docs/2019_chp_romania_romanian.pdf). Accessed September 26

García-Colón, I. 2020. The COVID-19 spring and the expendability of guestworkers. Dialectical Anthropology 44: 257-264. https://doi.org/10.1007/s10624-020-09601-6.

Long, Ling. 2020. In Beijing. London Review of Books. Vol. 42 No. 11

Mayer, A. 1975. The Lower Middle Class as Historical Problem. The Journal of Modern History. Volume 47, No. 3. https://doi.org/10.1086/241338

Mitrovic, M. 2020. Empty time (Peru under the pandemic). Dialectical Anthropology 44: 251-255. https:// doi.org/10.1007/s10624-020-09600-7.

Ortega, F., and M. Orsini. 2020. Governing COVID-19 without government in Brazil: Ignorance, neoliberal authoritarianism, and the collapse of public health leadership. Global Public Health 15 (9): 1257-1277. https://doi.org/10.1080/17441692.2020.1795223.

Poenaru, F. 2019. Social Democrats in Power. Romanian case. In The New Right and the Old Left in SouthEast Europe. Tranform Network. Available here: Accessed July 12 https://www.transform-network.net/ publications/issue/the-new-right-and-the-old-left-in-south-east-europe/ 
Poenaru, Florin, Rogozanu, Costi. 2020. Why social distancing "doesn't apply" to Germany's migrant farmworkers. Jacobin. Available here: https://www.jacobinmag.com/2020/05/romanian-migrant-farmworkers-germany-european-union-coronavirus. Accessed July 12.

Roy, A. 2021. We are witnessing a crime against humanity': Arundhati Roy on India's Covid catastrophe. The Guardian. Available here: https://www.theguardian.com/news/2021/apr/28/crime-against-human ity-arundhati-roy-india-covid-catastrophe. Accessed September 20

Tamas, G. 2001. What is post-fascism. OpenDemocracy. Available here: https://www.opendemocracy.net/en/ article_306jsp/. Accessed July 12.

Publisher's note Springer Nature remains neutral with regard to jurisdictional claims in published maps and institutional affiliations. 